\title{
Pengaruh Perubahan Penggunaan Lahan Terhadap Limpasan Menggunakan Multidata Iklim Satelit di Sub DAS Samin
}

\section{Endi Ramadhani, Slamet Suprayogi, Mohammad Pramono Hadi}

Masuk: 22122020 / Diterima: 17012021 / Dipublikasi: 30062021

\begin{abstract}
The Samin Subwatershed is part of the Bengawan Solo river basin, which is included in 15 critical national priority river basins. Many hydrological studies have shown changes in the hydrological response due to land-use changes in the Samin Subwatershed. One approach in assessing the watershed's criticality level and hydrological response is to assess the runoff conditions using SWAT hydrological modeling. On the other hand, many existing hydrological modeling studies are still limited to using observational climate data, while the use of multi-satellite climate data using the SWAT hydrological model has shown the potential for a good catchment hydrological assessment. Three primary research objectives of the Samin Subwatershed between 2004 and 2013 are: analyzing the distribution and changes in land use, analyze the accuracy of runoff simulation results using satellite climate data grids, and analyze the effect of land-use change on runoff. The research method used is descriptive-analytic with SWAT modeling, field observation, and Pearson correlation method analysis. The results showed that land use in the Samin Subwatershed between 2004 and 2013 has a diverse and heterogeneous distribution pattern. Interpretation results show a trend of changes in sizeable dense vegetation to medium-sized low vegetation triggered by intensive land utilization activities. Based on the five types of satellite rainfall dataset, the TRMM data has shown the best accuracy, caused by the suitability of the data specification with the typology of the Samin Subwatershed as the tropical catchment area. The insignificant effect of land-use changes on runoff in the Samin Subwatershed, based on technically modeling, is caused by the uncertainty of the model analysis results. Theoretically, hydrological is caused by differences in treatment/management systems for each type of model land-use in the same land unit.
\end{abstract}

Keywords: Samin Subwatershed; SWAT Hydrological Model; Multi Satellite Climate Data; Landuse Change; Runoff

Abstrak Sub DAS Samin sebagai bagian dari DAS Bengawan Solo, termasuk dalam 15 DAS kritis prioritas nasional. Banyak kajian hidrologi yang telah menunjukkan adanya perubahan respon hidrologi akibat perubahan penggunaan lahan. Salah satu pendekatan dalam menilai tingkat kekritisan dan respon hidrologi DAS adalah dengan mengkaji kondisi limpasan dengan pemodelan hidrologi SWAT. Namun di sisi lain, dari banyak kajian pemodelan hidrologi yang ada, masih terbatas pada penggunaan data iklim observasi; sedangkan pemanfaatan multidata iklim satelit dengan model hidrologi SWAT, telah menunjukkan potensi akurasi kajian hidrologi DAS yang baik. Tiga dasar tujuan penelitian di Sub DAS Samin antara tahun 2004 dan 2013 yaitu menganalisis persebaran dan perubahan penggunaan lahan, menganalisis akurasi hasil simulasi limpasan menggunakan data grid iklim satelit dan menganalisis pengaruh perubahan penggunaan lahan terhadap limpasan. Metode penelitian yang digunakan adalah deskriptif analitik dengan pemodelan SWAT, identifikasi kondisi lapangan, serta analisis korelasi Pearson. Hasil penelitian menunjukkan bahwa tipe penggunaan lahan di Sub DAS Samin antara tahun 2004 dan 2013, memiliki persebaran yang beragam dan bersifat heterogen, dengan hasil interpretasi menunjukkan tren perubahan vegetasi rapat berukuran besar ke vegetasi rendah berukuran sedang, yang dipicu oleh adanya pemanfaatan lahan intensif. Dari lima jenis dataset curah hujan satelit, data TRMM memiliki akurasi terbaik, karena kecocokan spesifikasi data dengan tipologi Sub DAS Samin sebagai kawasan DAS beriklim tropis. Tidak signifikannya pengaruh perubahan penggunaan lahan terhadap limpasan di Sub DAS Samin, secara teknis pemodelan disebabkan oleh adanya ketidakpastian hasil analisis model dan secara teoritis hidrologi disebabkan oleh perbedaan tata perlakuan/sistem manajemen pada masingmasing tipe penggunaan lahan dalam satuan lahan yang sama. 
Kata kunci: Sub DAS Samin; Model Hidrologi SWAT; Multidata Iklim Satelit; Perubahan Penggunaan Lahan; Limpasan

This is an open access article under the CC BY-SA license.

Copyright $\odot 2021$ by Author. Published by Universitas Pendidikan Ganesha.

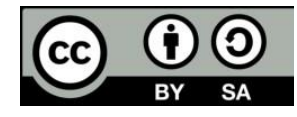

\section{Pendahuluan}

Daerah Aliran Sungai (DAS) sebagai kawasan ekosistem, tersusun dalam suatu sistem hidrologi yang bagiannya mempunyai hubungan saling ketergantungan yang sangat kuat secara hidrologis (Ditjen PEPDAS, 2017). Secara sederhana, proses hidrologi dalam suatu DAS dapat digambarkan dengan adanya hubungan antara unsur masukan berupa hujan, proses, dan keluaran berupa aliran (Hadi, 2017). DAS sebagai kawasan ekosistem dengan berbagai fungsinya, memiliki peran yang esensial dalam menunjang kehidupan di dalamnya, sehingga kondisinya secara hidrologis dan ekologis harus selalu seimbang. Laporan BNPB tahun 2016 menyatakan bahwa dari 450 DAS yang ada di Indonesia, 118 DAS diantaranya berada dalam kondisi kritis. DAS Bengawan Solo merupakan salah satu dari 15 DAS kritis prioritas dalam RPJMN tahun 2015-2019 (Bappenas, 2014; Ditjen PEPDAS, 2017). Sub DAS Samin sebagai bagian dari Wilayah Satuan Kerja DAS Bengawan Solo, memiliki luas wilayah 220,36 km² merupakan bagian dari DAS Bengawan Solo, Provinsi Jawa Tengah, yang secara geografis terletak di lereng barat Gunung Lawu pada garis koordinat

Endi Ramadhani, Slamet Suprayogi, Mohammad Pramono Hadi

Universitas Gadjah Mada, Indonesia

endiramadhani@rocketmail.com
07'36'36" - 0741'47" LS dan 110 $50^{\prime} 41^{\prime \prime}$ - 111'11'16" BT. Secara administratif Sub DAS Samin berada di dua wilayah kabupaten, yaitu Karanganyar dan Sukoharjo. Tipologi kawasan Sub DAS Samin dengan ketinggian 89-3.114 mdpl, merupakan kawasan pegunungan beriklim tropis dengan pengaruh angin monsun Asia dan Australia, serta tergolong tipe iklim C (kriteria agak basah) dalam klasifikasi Schmidt-Ferguson. Adapun puncak curah hujan bulanan tertinggi pada Bulan Januari dan terendah pada Bulan Agustus.

Dari banyak kajian hidrologi yang telah dilakukan menunjukkan adanya kekritisan dan perubahan respon hidrologi di Sub DAS Samin akibat perubahan penggunaan lahan. Hasil kajian Retnowati (2012), menyatakan bahwa pada bagian unit terkecil Sub DAS Samin, yaitu Sub DAS Ngunut I dan Sub DAS Tapan mengalami ketidakstabilan aliran, yang dibuktikan pada peningkatan nilai variasi debit tahunan Budiarti, dkk. (2018) menunjukkan bahwa tingkat kerawanan banjir di Sub DAS Samin mencapai $83,05 \%$ dari total luas DAS, yang terdapat pada bagian tengah dan hilir. Kemudian Marhaento, dkk. (2017) dengan model SWAT di Sub DAS Samin, menyatakan bahwa terjadinya deforestasi dan ekspansi kawasan permukiman meningkatkan rerata debit tahunan selama 24 tahun (1990-2013) 
yang disebabkan oleh meningkatnya kawasan impervious, yang berujung pada menurunnya kemampuan infiltrasi tanah terhadap air hujan.

Secara hidrologis, salah satu indikator untuk mengestimasi tingkat kekritisan dan respon hidrologi suatu DAS, dapat dinilai dari kemampuan DAS dalam merespon air hujan yang dapat direpresentasikan dari besaran limpasan (runoff) (Sancayaningsih dkk., 2017). Besarnya kondisi limpasan tergantung pada kondisi fisik suatu lahan, meliputi jenis vegetasi yang menutup lahan, serta bagaimana perlakuan manusia dalam memanajemen lahan tersebut (Sudarmadji dkk., 2016). Berdasarkan RTRW Provinsi Jateng tahun 20092029, Sub DAS Samin merupakan salah satu kawasan strategis sektor agropolitan (Pemprov Jateng, 2018). Hal tersebut secara langsung, maupun tidak langsung berimplikasi pada terjadinya perubahan penggunaan lahan, yang kemudian mempengaruhi perubahan kondisi limpasan di Sub DAS Samin dan secara lanjut berkaitan dengan terjadinya bencana banjir dan erosi. Mendasari permasalahan yang tersebut, maka esensi dari dilakukannya studi kajian DAS dengan pendekatan spasial ekologis menjadi sangat penting dilakukan (Sancayaningsih, dkk. 2017). Salah satu pendekatan yang dapat dilakukan dalam mengkaji kondisi limpasan adalah dengan pemodelan hidrologi SWAT.

Soil and Water Assessment Tool (SWAT) merupakan aplikasi model hidrologi terdistribusi berbasis fisik, yang neraca air menjadi faktor dasar utama, yang digunakan dalam memahami dan menganalisis apapun fenomena hidrologi yang terjadi dalam suatu kawasan DAS (Neitsch dkk., 2011). Konsep persamaan neraca air dalam analisis pemodelan SWAT ditunjukkan pada persamaan 1 .

$S W_{t}=S W_{0}+\sum_{i=1}^{t}\left(R_{\text {day }}-Q_{\text {surf }}-E_{a}-W_{\text {seep }}-Q_{g w}\right)(1)$

Dimana: $S W_{t}$ kandungan air tanah akhir $(\mathrm{mm}), S W_{0}$ kandungan air tanah awal pada hari ke-i $(\mathrm{mm}), R_{\text {day }}$ jumlah curah hujan hari ke-i (mm), $Q_{\text {surf }}$ jumlah limpasan pada hari ke-i (mm), $E_{a}$ jumlah evapotranspirasi pada hari ke-i $(\mathrm{mm}), W_{\text {seep }}$ jumlah air masuk ke zona vadose pada profil tanah hari ke-i (mm), $Q_{g w}$ jumlah air yang kembali hari ke-i $(\mathrm{mm})$.

Model SWAT memiliki reputasi yang baik dalam penggunaannya dan telah berhasil diterapkan pada banyak kawasan pertanian dalam suatu DAS dengan kondisi iklim yang berbeda (Ang dan Oeurng, 2018). Selain itu, model SWAT dapat diaplikasikan dalam menilai respon hidrologi suatu daerah tangkapan dengan pendekatan neraca air yang didasari oleh skenario perubahan penggunaan lahan (Fohrer dkk., 2001; Welde dan Gebremariam, 2017). Akan tetapi, dari kajian model SWAT yang ada di Indonesia saat ini cenderung terbatas, hanya pada kawasan DAS dengan data observasi yang memadai dari aspek resolusi spasial dan temporal; sedangkan banyak kawasan DAS lain yang langka akan data, sehingga mempersulit dilakukannya kajian hidrologi kawasan DAS, Namun di sisi lain, ketersediaan data iklim satelit saat ini sangat beragam dan mudah diakses. Selain dapat mengatasi permasalahan kelangkaan data, data iklim satelit juga 
berpotensi menjadi alternatif praktis dalam meningkatkan akurasi hasil analisis pemodelan kondisi hidrologi suatu DAS. Namun di sisi lain, data iklim satelit memiliki kelemahan pada akurasinya dalam mengestimasi ketebalan hujan aktual di lapangan, serta dengan adanya efek bias yang umumnya terdapat pada data iklim satelit, menyebabkan hasil analisis cenderung bersifat overanalysis, sehingga setiap variasi data yang tersedia perlu diuji kemampuannya. Atas dasar rumusan permasalahan yang telah dibahas, maka dapat ditentukan tujuan penelitian sebagai berikut. Pertama, menganalisis persebaran dan perubahan penggunaan lahan di Sub DAS Samin antara tahun 2004 dan 2013. Kedua, menganalisis akurasi hasil simulasi limpasan di Sub DAS Samin menggunakan data grid iklim satelit antara tahun 2004 dan 2013. Terakhir, menganalisis pengaruh perubahan penggunaan lahan terhadap limpasan di Sub DAS Samin.

\section{Metode}

Metode yang digunakan dalam penelitian ini adalah deskriptif analitik (statistik, tabulasi) dengan pemodelan hidrologi SWAT, kajian kondisi lapangan, serta analisis korelasi Pearson atau Product Moment untuk menganalisis pengaruh perubahan penggunaan lahan terhadap limpasan di Sub DAS Samin. Secara garis besar, desain penelitian dan pengembangan instrumen penelitian ini terbagi dalam tiga tahapan, yaitu pre processing, processing, dan post processing, yang secara sistematis dapat diilustrasikan pada Gambar 1.

\section{Persiapan Basis Data Analisis Model SWAT}

Lingkup proses dalam mempersiapkan basis data terdiri dari beberapa kegiatan, yaitu akuisisi, pengolahan data (ekstraksi dan konversi), serta penyusunan peta penggunaan lahan tentatif. Himpunan multidata iklim satelit yang dirincikan pada Tabel 1, digunakan dalam simulasi model SWAT. Adapun 5 jenis data curah hujan yang berbeda diterapkan guna mendapatkan simulasi limpasan terbaik, yang kemudian dievaluasi hubungannya terhadap perubahan penggunaan lahan.

Tabel 1. Spesifikasi Data Meteorologis Berbasis Satelit Penelitian

\begin{tabular}{|c|c|c|c|}
\hline \multirow{2}{*}{$\begin{array}{l}\text { Himpunan Data } \\
\text { Curah Hujan }\end{array}$} & \multicolumn{2}{|c|}{ Resolusi } & \multirow[b]{2}{*}{ Sumber Data } \\
\hline & Spasial & Temporal & \\
\hline TRMM TMPA 3B42 & $0,25^{\circ}$ & Harian & Huffman dkk., 2007, NASA \\
\hline GPM-IMERG Final Run & $0,1^{\circ}$ & Harian & Huffman dkk., 2019, NASA \\
\hline CHIRPS & $0,05^{\circ}$ & Harian & Funk dkk., 2015, USGS, CHG \\
\hline CP-CMORPH & $0,05^{\circ}$ & Harian & Joyce dkk., 2004, NOAA \\
\hline CHRS Portal & $0,25^{\circ}$ & Harian & Ashouri dkk., 2015, University of California \\
\hline \multicolumn{4}{|c|}{ Temperatur Maksimum dan Minimum } \\
\hline$S A-O B S$ & $0,25^{\circ}$ & Harian & Van den Besselaar dkk., 2017, BMKG, KNMI \\
\hline \multicolumn{4}{|c|}{ Kelembapan Relatif, Radiasi Matahari, dan Kecepatan Angin } \\
\hline Era-Interim & $0,125^{\circ}$ & $3 \mathrm{Jam}$ & Dee dkk., 2011, ECMWF \\
\hline
\end{tabular}




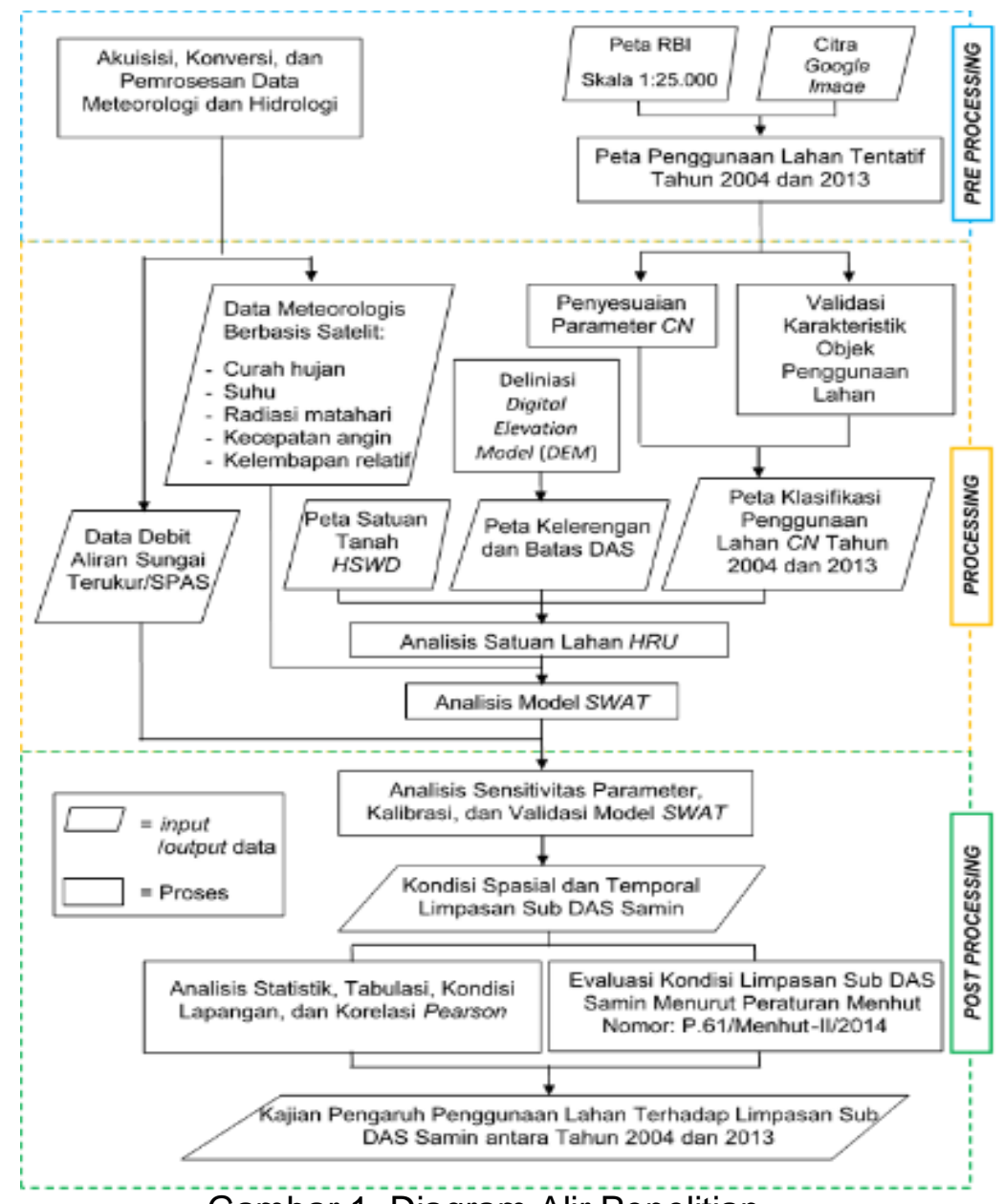

Gambar 1. Diagram Alir Penelitian

Masing-masing dataset pada

Tabel 1 dilakukan ekstraksi dan konversi menggunakan aplikasi phyton, NetCDF Operators (NCO), dan Open GRADS, untuk menyusun basis data model SWAT yang berformat text file (.txt). Selain itu, digunakan data Digital Elevation Model Nasional (DEMNAS) versi 1.0 resolusi 8,25 meter (BIG) dan peta tanah Harmonized World Soil Database (HWSD) skala 1:5.000.000 (Nachtergaele dkk., 2012; FAO; IIASA; ISHC; ISSCAS; IRC).

Penyusunan peta penggunaan lahan tentatif tahun 2004 dan 2013, dibangun dari peta RBI skala 1:25.000, yang kemudian ditingkatkan detail objek penggunaan lahan secara interpretasi visual/manual menggunakan Google Historical Image dan hasil perekaman $360^{\circ}$ dengan asumsi adanya kesamaan karakteristik objek penggunaan lahan, yang didasari unsur interpretasi dalam satuan lahan yang memiliki homogenitas.

\section{Penyesuaian Parameter Analisis Model SWAT}

SWAT sebagai model semi terdistribusi fisik membutuhkan pengaturan, serta penyesuaian parameter analisis, agar seakurat mungkin memberikan gambaran representatif dari karakteristik DAS dari segi hidrometeorologis dan tipologi fisiknya. Pada analsis satuan HRU ditentukan 
penyesuaian beberapa parameter, diantaranya klasifikasi lereng menurut Ditjen BPDASPS Nomor: P.3/VSET/2013 tentang Pedoman Karakteristik DAS. Klasifikasi penggunaan lahan dari peta penggunaan lahan tentatif disesuaikan pada klasifikasi model SWAT oleh Marhaento (2018), yaitu: Hutan Hijau/Forest Evergreen (FRSE), Kebun Campuran/Forest Mixed (FRST), Pertanian Lahan Kering/Agricultural Land-Row Crops (AGRR), Pertanian Padi Sawah/Rice (RICE), Permukiman/Residential-Medium

Density (URMD), Padang Rumput/Pasture (PAST), dan Tubuh Air/Water Body (WATR).

Pendekatan tipe distribusi $H R U$ secara multiple dengan penentuan nilai ambang batas (threshold) 10\% penggunaan lahan, 10\% tanah, dan $10 \%$ lereng, diterapkan atas dasar pertimbangan fokus analisis penelitian, yaitu limpasan dan kemampuan sumber daya komputasi yang dimiliki. Metode elevation band yang bertujuan untuk mempertimbangkan efek orografis dan meningkatkan akurasi output model (Arnold dkk., 2012; Tuo dkk., 2016) diterapkan dalam pemodelan dengan jarak interval 100 meter dari 5 elevation band.
Pada dasarnya model SWAT dikembangkan untuk kawasan pertanian DAS beriklim sedang, sehingga kriteria penggunaan lahan untuk kawasan tropis perlu disesuaikan (Kilonzo, 2014). Atas dasar hal tersebut, dilakukan penyesuaian kriteria parameter penggunaan lahan pada basis data tanaman model SWAT oleh Marhaento (2018) pada Tabel 2.

Menurut Neitsch et al. (2011) nilai $C N$ untuk kondisi $A M C$ // dalam model SWAT, hanya sesuai untuk kondisi lereng $5 \%$; sedangkan daerah penelitian merupakan kawasan DAS pegunungan tropis dengan kriteria lereng yang beragam, sehingga penerapan nilai $C N$ menjadi tidak relevan. Oleh karena itu, diterapkan penyesuaian $C N$ pada kondisi lereng yang berbeda atau lebih dari $5 \%$, oleh Williams (1995) pada persamaan 2.

$C N_{2 S}=\frac{\left(C N_{3}-C N_{2}\right)}{3} \cdot[(1-2 \cdot \exp (-13,86 \cdot s l p))]+C N_{2}(2)$

Dimana: $C N_{2 S}$ adalah bilangan kurva kondisi kelembapan II yang disesuaikan untuk lereng, $\mathrm{CN}_{3}$ adalah bilangan kurva kondisi kelembapan III untuk standar lereng $5 \%, \mathrm{CN}_{2}$ adalah bilangan kurva kondisi kelembapan II untuk standar lereng 5\%, s/p adalah pecahan rerata kelerengan dari Sub DAS.

Tabel 2. Kriteria Tipe Penggunaan Lahan Spesifik untuk Basis Data Tanaman dan Manajemen Model SWAT

\begin{tabular}{lcccccc}
\hline \multirow{2}{*}{$\begin{array}{l}\text { Variabel } \\
\text { (Satuan) }\end{array}$} & \multicolumn{6}{c}{ Klasifikasi Tipe Penggunaan Lahan } \\
\cline { 2 - 7 } & Standar & Penyesuaian & Standar & Penyesuaian & Standar & Penyesuaian \\
\hline LAI_INIT (-) & 0 & 5 & 0 & 3 & 0 & 3 \\
\hline BIO_INIT(kg/ha) & 0 & $1.000^{*}$ & 0 & 0 & 0 & 0 \\
\hline PHU_LT (-) & 0 & $3.500^{*}$ & 0 & $3.500^{*}$ & 0 & $3.500^{*}$ \\
\hline GSI (mm/dtk) & 2 & 7 & 5 & 5 & 7 & 7 \\
\hline CANMX (mm) & 0 & 5 & 0 & 2 & 0 & 2 \\
\hline Keterangan : ${ }^{*}=$ Nilai maksimum yang diizinkan SWAT; (-) tidak terdefinisi & & \\
\hline Sumber: Marhaento (2018) & \multicolumn{7}{c}{}
\end{tabular}


Simulasi model SWAT penelitian ini diterapkan periode warm up 3 tahun (2001-2003) sebelum periode analisis yang dilakukan selama 10 tahun, yaitu antara tahun 2004 dan 2013 dalam interval waktu bulanan. Selain itu, metode analisis dinamika perubahan penggunaan lahan terhadap limpasan menerapkan pendekatan hasil kajian Nguyen (2020) dengan kode program $R$ Studio.

\section{Analisis Sensitivitas Parameter, Kalibrasi, dan Validasi}

Program SWAT Calibration and Uncertainty Procedures (SWAT-CUP) dan metode Sequential Uncertainty Fitting Version-2 (SUFI-2) digunakan dalam analisis sentivitas parameter, kalibrasi, dan validasi. Penentuan parameter secara sentivitas global (global sensitivity) diterapkan dalam menentukan 16 parameter terpilih (CN2, ALPHA_BF, GW_DELAY, GWQMN, RCHRG_DP, REVAPMN, GW_REVAP, ESCO, EPCO, CANMAX, OV_N, SOL_AWC, SOL_K, ALPHA_BNK, CH_K2, CH_N2), yang dianggap berperan dalam proses hidrologi di Sub DAS Samin. Pendekatan kalibrasi dan validasi menurut Klemes (1986), yaitu secara dua waktu terpisah (differential splitsample test) dengan pembagian $70 \%$ kalibrasi di periode awal dan $30 \%$ validasi di periode akhir diterapkan dalam periode simulasi model. Data Tinggi Muka Air (TMA) bulanan Sub DAS Samin oleh Direktorat Jenderal Sumberdaya Air, Balai Besar Wilayah Sungai Bengawan Solo, Kementerian PU, digunakan dalam kalibrasi dan validasi simulasi model Sub DAS Samin.
Moriasi dkk. (2007) menyatakan bahwa kombinasi penilaian akurasi pemodelan dengan teknik grafis dan multistatistik harus digunakan dan direkomendasikan. Atas dasar hal tersebut, penilaian grafik distribusi probabilitas ketidakpastian prediksi 95\% (95PPU), yang disertai dua indikator statistik, yaitu faktor $P$ dan faktor $\mathrm{R}$ diterapkan. Menurut Abbaspour (2015) dari rentang distribusi grafik mencakup sebagian besar data observasi; sedangkan faktor $P$ dinilai dari nilai yang mencapai angka 1 dan faktor $R$ berada pada angka 0 . Selain itu, tiga metode penilaian akurasi model diterapkan dalam penelitian ini, yaitu Coefficient of Determination $\left(\mathrm{R}^{2}\right)$, Nash-Sutcliffe Efficiency ( $\left.\mathrm{N}_{\mathrm{SE}}\right)$, dan Percent Bias (PBIAS) yang tingkatan performanya, secara periode analisis bulanan dinilai oleh Moriasi dkk. (2007) pada Tabel 3.

\section{Evaluasi Pengaruh Perubahan Penggunaan Lahan Terhadap Limpasan}

Penilaian kondisi limpasan perlu dilakukan untuk mengestimasi kaitannya pada perubahan penggunaan lahan yang terjadi. Adapun Peraturan Menhut Republik Indonesia Nomor: P.61/Menhut-II/2014 tentang Monitoring dan Evaluasi Pengelolaan DAS, digunakan dalam evaluasi kondisi limpasan, yang direpresentasikan dalam Koefisien Aliran Tahunan (KAT) yang konsep teoritisnya berdasarkan persamaan 3 .

$K A T=\frac{Q \text { tahunan }}{P \text { tahunan }}$

(3)

Dimana: $\mathrm{Q}$ adalah tebal limpasan $(\mathrm{mm})$ dan $P$ adalah tebal hujan ( $\mathrm{mm})$ 
Tabel 3. Tingkatan Performa Umum Menurut Statistik yang Direkomendasikan untuk Periode Analsis Bulanan

\begin{tabular}{lccc}
\hline Tingkatan Performa & $\mathrm{R}^{2}$ & $\mathrm{~N}_{\mathrm{SE}}$ & PBIAS debit aliran (\%) \\
\hline Sangat Baik & $0,70<\mathrm{R}^{2} \leq 1,00$ & $0,75<\mathrm{N}_{\mathrm{SE}} \leq 1,00$ & PBIAS $< \pm 10$ \\
\hline Baik & $0,60<\mathrm{R}^{2} \leq 0,70$ & $0,65<\mathrm{N}_{\mathrm{SE}} \leq 0,75$ & $\pm 10 \leq \mathrm{PBIAS}< \pm 15$ \\
\hline Memuaskan & $0,50<\mathrm{R}^{2} \leq 0,60$ & $0,50<\mathrm{N}_{\mathrm{SE}} \leq 0,65$ & $\pm 15 \leq \mathrm{PBIAS}< \pm 25$ \\
\hline Kurang Memuaskan & $\mathrm{R}^{2} \leq 0,50$ & $\mathrm{~N}_{\mathrm{SE}} \leq 0,50$ & PBIAS $\geq \pm 25$
\end{tabular}

Sumber: Moriasi dkk. (2007), dengan modifikasi

\begin{tabular}{llll}
\multicolumn{2}{c}{ Setelah didapatkan } & nilai & Monitoring dan Evaluasi Pengelolaan \\
Koefisien Aliran Tahunan & (KAT), & DAS untuk menaksir kondisi limpasan \\
dilakukan pengklasifikasian menurut & di Sub DAS Samin, yang ditampilkan \\
Peraturan Menhut tentang Standar & pada Tabel 4.
\end{tabular}

Tabel 4. Kriteria, Nilai, dan Klasifikasi Koefisien Aliran Tahunan (KAT)

\begin{tabular}{lcc}
\hline Kriteria & Nilai & Klasifikasi \\
\hline \multirow{3}{*}{ Koefisien Aliran } & KAT $\leq 0,2$ & Sangat Rendah \\
\cline { 2 - 3 } Tahunan (KAT) & $0,2<$ KAT $\leq 0,3$ & Rendah \\
\cline { 2 - 3 } & $0,3<$ KAT $\leq 0,4$ & Sedang \\
\cline { 2 - 3 } & $0,4<$ KAT $\leq 0,5$ & Tinggi \\
\hline
\end{tabular}

Sumber: Peraturan Menhut tentang Monev Pengelolaan DAS, Nomor: P.61/Menhut-II/2014

Estimasi pengaruh perubahan penggunaan lahan terhadap limpasan didasarkan oleh variabel luasan perubahan penggunaan lahan yang dominan menurut luasannya antara tahun 2004 dan 2013, atas dasar sangat tidak merata atau heterogennya persebaran satuan penggunaan lahan di Sub DAS Samin, sehingga mengakibatkan tidak normalnya distribusi data yang akan diuji.

Metode korelasi Pearson atau Product Moment dengan aplikasi SPSS Statistic 26, digunakan dalam mengevaluasi pengaruh dari hubungan antara kedua variabel, yaitu perubahan penggunaan lahan dominan dan kondisi limpasan menurut Koefisien Aliran Tahunan (KAT) di Sub DAS Samin.

\section{Hasil dan Pembahasan} Persebaran dan Perubahan Penggunaan Lahan Sub DAS Samin

Secara statistik dan spasial, kondisi persebaran dan perubahan penggunaan lahan di Sub DAS Samin dapat ditunjukkan pada Tabel 5 dan Gambar 2. Distribusi penggunaan lahan Sub DAS Samin pada Tabel 5, menunjukkan kecenderungan dominasi tipe penggunaan lahan yang tergolong dalam lahan yang dimanfaatkan secara intensif, berupa dominasi kawasan pertanian padi sawah, kebun campuran, permukiman, dan pertanian lahan kering. Sedangkan di sisi lain, kawasan hutan hijau, padang rumput, dan tubuh air menjadi tipe penggunaan lahan minor di Sub DAS Samin antara tahun 2004 dan 2013. Secara spasial pada Gambar 2, persebaran tipe penggunaan lahan di Sub DAS Samin 
antara tahun 2004 dan 2013, menunjukkan kecenderungan persebaran yang heterogen dengan pola yang khas pada tiap penggunaan lahan.

Hutan hijau yang secara aktual lapangan terdiri dari vegetasi pohon pinus, cenderung tersebar pada kawasan dengan elevasi tinggi pada hulu DAS. Kebun campuran sebagai kawasan hutan yang terdiri dari vegetasi pepohonan yang dimanfaatkan, keberadaannya cenderung bersinggungan dengan kawasan hutan hijau atau di sekitar area permukiman. Pertanian padi sawah, yang merupakan lahan pertanian dengan sistem irigasi yang intensif, cenderung berada pada kawasan dengan kondisi lereng datar pada bagian tengah, hingga hilir DAS. Kemudian permukiman yang umumnya merupakan tipe permukiman pedesaan, tersebar pada seluruh kawasan DAS dan cenderung terpusat pada sistem jaringan jalan.

Perubahan penggunaan lahan di Sub DAS Samin antara tahun 2004 dan 2013 pada Tabel 5 dan Gambar 2, menunjukkan kecenderungan penambahan luasan pada kawasan bervegetasi rendah dengan kerapatan jarang, seperti pertanian lahan kering, pertanian padi sawah, permukiman, dan padang rumput. Lain daripada itu, tren kecenderungan pengurangan luasan terjadi pada kawasan dengan kriteria vegetasi besar dan kerapatan tinggi, seperti kawasan hutan hijau dan kebun campuran.

Tabel 5. Persebaran dan Perubahan Penggunaan Lahan di Sub DAS Samin Tahun 2004 dan 2013

\begin{tabular}{|c|c|c|c|c|c|c|}
\hline \multirow[t]{2}{*}{$\begin{array}{l}\text { Klasifikasi Penggunaan Lahan } \\
\text { (Kode Model SWAT) }\end{array}$} & \multicolumn{2}{|c|}{$\begin{array}{l}\text { Luas } \\
\text { Tahun } 2004\end{array}$} & \multicolumn{2}{|c|}{$\begin{array}{l}\text { Luas } \\
\text { Tahun } 2013\end{array}$} & \multicolumn{2}{|c|}{$\begin{array}{c}\text { Luas Perubahan } \\
\text { Penggunaan } \\
\text { Lahan } \\
2004 \text { dan } 2013\end{array}$} \\
\hline & $\mathrm{km}^{2}$ & $\%$ & $\mathrm{~km}^{2}$ & $\%$ & $\mathrm{~km}^{2}$ & $\%$ \\
\hline Hutan Hijau (FRSE) & 20,53 & 9,32 & 12,81 & 5,81 & $-7,72$ & 24,36 \\
\hline Kebun Campuran (FRST) & 64,61 & 29,32 & 56,49 & 25,64 & $-8,12$ & 25,62 \\
\hline $\begin{array}{l}\text { Pertanian Lahan Kering } \\
(A G R R)\end{array}$ & 38,69 & 17,57 & 40,45 & 18,36 & 1,76 & 5,55 \\
\hline Pertanian Padi Sawah (RICE) & 55,81 & 25,33 & 63,51 & 28,82 & 7,70 & 24,30 \\
\hline Padang Rumput (PAST) & 0,42 & 0,19 & 0,49 & 0,22 & 0,07 & 0,22 \\
\hline Permukiman (URMD) & 39,91 & 18,11 & 46,23 & 20,98 & 6,32 & 19,94 \\
\hline Tubuh Air (WATR) & 0,38 & 0,17 & 0,38 & 0,17 & 0,00 & 0,00 \\
\hline Total & 220,36 & 100 & 220,36 & 100 & 31,69 & 100 \\
\hline
\end{tabular}




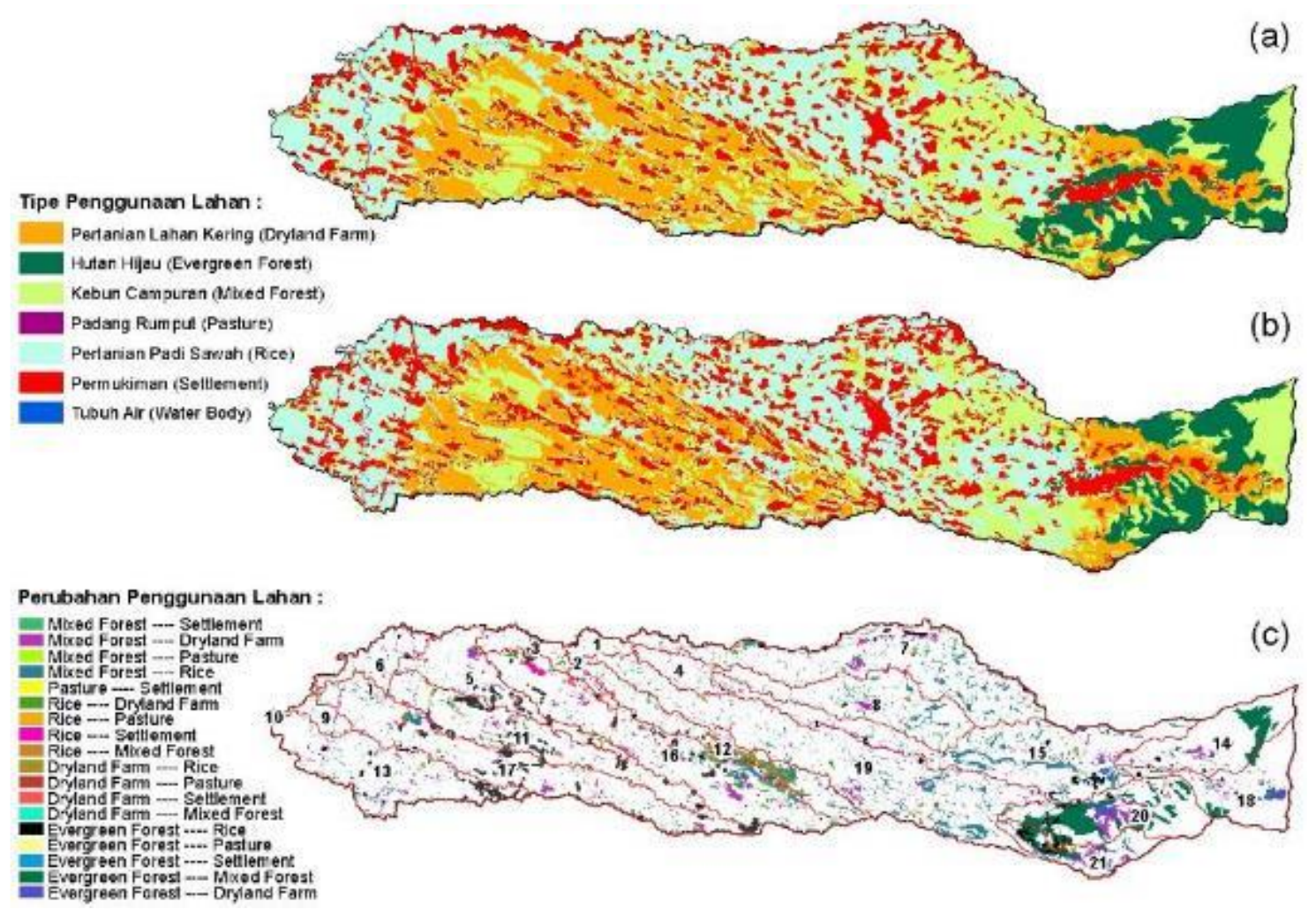

Gambar 2. (a) Persebaran Penggunaan Lahan Tahun 2004; (b) Persebaran Penggunaan Lahan Tahun 2013; (c) Perubahan Penggunaan Lahan antara Tahun 2004 dan 2013

\section{Evaluasi Akurasi Simulasi Limpasan Model SWAT}

1) Sensitivitas Parameter

Hasil analisis sensitivitas parameter dari 16 parameter yang mewakili perilaku hidrologi di Sub DAS Samin, dengan penerapan 5 data curah hujan satelit yang berbeda dapat ditunjukkan pada Tabel 6. Hasil menunjukkan bahwa tiap dataset curah hujan memiliki identifikasi yang berbeda dalam menilai parameter yang paling berpengaruh pada limpasan.

Data TRMM mengidentifikasi faktor penggunaan lahan, tanah, dan lereng pada kondisi kelembapan anteseden II (CN2), data GPM Final
Run menilai faktor proses airtanah pada kondisi aliran dasar (ALPHA_BF), data CMORPH dan CHRS Portal menilai faktor konduktivitas hidrolik pada jaringan sungai utama ( $\mathrm{CH} \_\mathrm{K} 2$ ), serta data CHIRPS yang menilai faktor tanah pada kondisi konduktivitas hidrolik jenuh tanah (SOL_K). Perbedaan identifikasi dari setiap dataset curah hujan satelit yang memiliki spesifikasi berbeda, pada dasarnya sangat mempengaruhi prediksi parameter sebagai representasi dari proses hidrologi yang berlangsung dalam sistem kawasan DAS, termasuk limpasan. 
Tabel 6. Hasil Analisis Sensitivitas Parameter Model SWAT di Sub DAS Samin

\begin{tabular}{cccccc}
\hline Urutan Sensitivitas & TRMM & GPM Final Run & CMORPH & CHRS Portal & CHIRPS \\
\hline 1 & CN2 & ALPHA_BF & CH_K2 & CH_K2 & SOL_K \\
\hline 2 & GW_DELAY & RCHRG_DP & CN2 & CN2 & CH_N2 \\
\hline 3 & GWQMN & ESCO & GW_DELAY & GW_REVAP & ALPHA_BNK \\
\hline 4 & OV_N & CN2 & SOL_AWC & GW_DELAY & GWQMN \\
\hline 5 & GW_REVAP & CANMX & OV_N & GWQMN & CANMX \\
\hline 6 & EPCO & SOL_K & GWQMN & OV_N & ESCO \\
\hline 7 & CH_K2 & EPCO & RCHRG_DP & EPCO & CH_K2 \\
\hline 8 & REVAPMN & GW_REVAP & REVAPMN & ESCO & EPCO \\
\hline 9 & CANMX & CH_N2 & ALPHA_BNK & RCHRG_DP & ALPHA_BF \\
\hline 10 & ESCO & GW_DELAY & CH_N2 & CH_N2 & REVAPMN \\
\hline 11 & ALPHA_BNK & OV_N & SOL_K & ALPHA_BNK & RCHRG_DP \\
\hline 12 & ALPHA_BF & GWQMN & CANMX & REVAPMN & OV_N \\
\hline 13 & SOL_K & CH_K2 & ALPHA_BF & ALPHA_BF & GW_REVAP \\
\hline 14 & RCHG_PD & REVAPMN & GW_REVAP & SOL_AWC & CN2 \\
\hline 15 & SOL_AWC & SOL_AWC & ESCO & SOL_K & GW_DELAY \\
\hline 16 & CH_N2 & ALPHA_BNK & EPCO & CANMX & SOL_AWC \\
\hline
\end{tabular}

Sumber: Hasil Analisis SWAT-CUP

2) Kalibrasi dan Validasi

Secara teoritis, banyak faktor yang dapat mempengaruhi akurasi simulasi model SWAT, diantaranya faktor resolusi spasial dan temporal data yang digunakan (Tan dkk., 2017; Yin dkk., 2016; Yang dkk., 2016), faktor efek bias pada data curah hujan (Bitew dkk., 2012), ketersediaan data debit aliran di setiap outlet DAS yang dikaji (Marhaento, 2018; Yang dkk., 2016), serta faktor algoritma dari data satelit yang digunakan dalam pemodelan (Tan dkk., 2017; Bitew dan Gebremichael, 2011). Pada penelitian ini proses kalibrasi dilakukan sebanyak 5 kali iterasi dengan 500 simulasi per iterasinya dan validasi 1 kali iterasi dengan 500 simulasi. Hasil kalibrasi dan validasi di Sub DAS Samin secara statistik dan hidrograf dapat ditampilkan pada Gambar 3 dan Tabel 7.

Hasil kalibrasi dan validasi pada Gambar 3 dan Tabel 7, menunjukkan bahwa seluruh dataset iklim satelit mampu mensimulasikan proses hidrologi di Sub DAS Samin, namun dengan tingkatan akurasi yang berbeda. Perbedaan akurasi model pada dasarnya dipicu oleh ketidakpastian pada input data curah hujan yang digunakan (Tuo dkk., 2016; Sirisena dkk., 2018). Selain itu, dari pola hidrograf menunjukkan bahwa seluruh dataset lemah dalam mesimulasikan kejadian debit puncak, yang menurut Tuo dkk. (2016) dan Pereira dkk. (2016) disebabkan oleh lemahnya kapasitas data dalam merepresentasikan variabilitas spasial dan temporal dari kejadian hujan.

Hasil akurasi model SWAT pada Tabel 7, menunjukkan bahwa data TRMM sebagai data curah hujan satelit dengan akurasi simulasi terbaik dari keempat dataset lainnya, yaitu akurasi kalibrasi $R^{2}$ 0,52, $N_{S E} 0,52$, PBIAS -1,2, dan validasi $R^{2} 0,68, N_{S E} 0,67$, PBIAS 1,6. Hal tersebut menunjukkan bahwa faktor resolusi spasial data tidak signifikan dalam mempengaruhi akurasi simulasi model, yang mana data dengan resolusi lebih tinggi, yaitu CHIRPS $\left(0,05^{\circ}\right)$ dan GPM Final Run $\left(0,1^{\circ}\right)$, menghasilkan akurasi yang lebih rendah daripada data $\operatorname{TRMM}\left(0,25^{\circ}\right)$. 
Tabel 7. Nilai Statistik Kalibrasi dan Validasi Model SWAT di Sub DAS Samin

\begin{tabular}{lcccccccccc}
\hline \multirow{2}{*}{ Data } & \multicolumn{4}{c}{ Statistik Kalibrasi } & \multicolumn{5}{c}{ Statistik Validasi } \\
\cline { 2 - 12 } & $\mathrm{p} \mathrm{val}$ & $\mathrm{r}$ fac & $\mathrm{R}^{2}$ & $\mathrm{~N}_{\mathrm{SE}}$ & PBIAS & $\mathrm{p}$ val & $\mathrm{r}$ val & $\mathrm{R}^{2}$ & $\mathrm{NSE}_{\mathrm{SE}}$ & $P B I A S$ \\
\hline TRMM 3B42 & 0,8 & 1,29 & 0,52 & 0,52 & $-1,2$ & 0,81 & 1,25 & 0,68 & 0,67 & 1,6 \\
\hline GPM Final Run & 0,5 & 0,59 & 0,48 & 0,48 & 1,3 & 0,42 & 0,54 & 0,61 & 0,59 & 10,5 \\
\hline CMORPH & 0,68 & 1,08 & 0,4 & 0,39 & 2,4 & 0,78 & 1,05 & 0,62 & 0,62 & 2 \\
\hline CHRS Portal & 0,77 & 1,43 & 0,43 & 0,43 & 3,8 & 0,75 & 1,48 & 0,69 & 0,69 & $-3,8$ \\
\hline CHIRPS & 0,47 & 0,92 & 0,5 & 0,4 & 16,6 & 0,39 & 0,58 & 0,5 & 0,44 & 16,3 \\
\hline
\end{tabular}

Sumber: Hasil Analisis SWAT-CUP

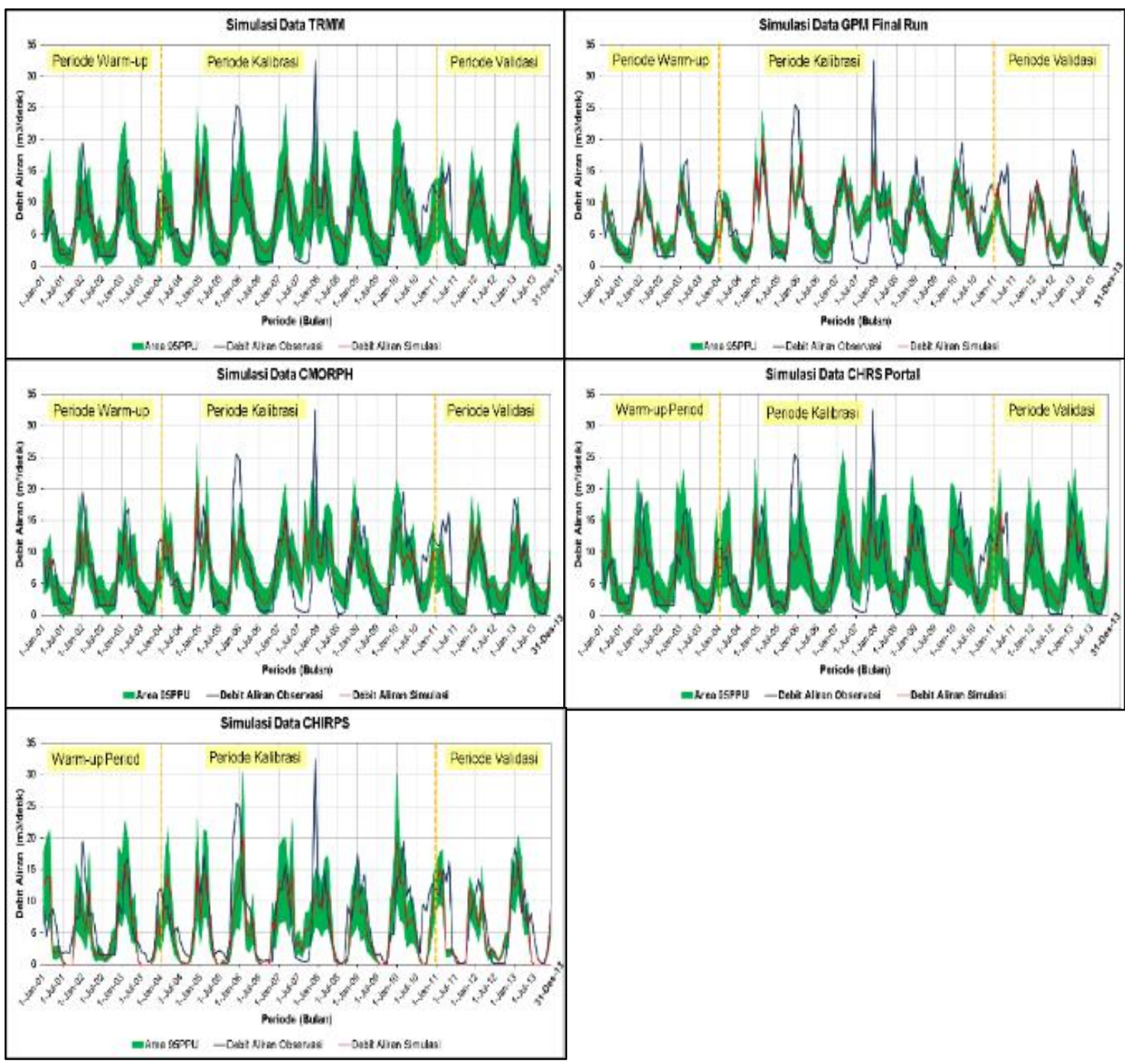

Gambar 3. Hidrograf Kalibrasi dan Validasi Lima Data Curah Hujan Satelit di Sub DAS Samin

Dari sekian faktor yang tidak signifikan pengaruhnya pada akurasi simulasi model SWAT, menunjukkan bahwa faktor spesifikasi data memiliki implikasi yang erat terhadap keakuratan simulasi model yang dikerjakan. Adapun data TRMM merupakan data curah hujan yang digunakan untuk memantau dan mempelajari curah hujan pada kawasan 
tropis dan sub tropis (Huffman dkk., 2019); sedangkan tipologi Sub DAS Samin merupakan kawasan DAS pegunungan beriklim tropis. Hal tersebut sejalan dengan kajian Bitew dan Gebremichael (2011) yang menyatakan bahwa kegunaan data curah hujan satelit ditentukan oleh kesesuaiannya dalam penggunaannya di wilayah tertentu. Atas dasar hal tersebut, pemahaman dari spesifikasi data terhadap kesesuaiannya pada kondisi kawasan DAS yang dikaj, menjadi hal yang penting dan krusial untuk menentukan penggunaan data yang tepat dan mendapatkan akurasi pemodelan yang terbaik.

\section{Pengaruh \\ Perubahan \\ Penggunaan Lahan Terhadap Limpasan}

Analisis pengaruh perubahan penggunaan lahan terhadap limpasan di Sub DAS Samin, dinilai dari hubungan antara dua variabel, yaitu perubahan penggunaan lahan yang didasarkan oleh perubahannya yang paling dominan dari segi luasan dan kondisi limpasan berdasarkan nilai
Koefisien Aliran Tahunan (KAT), yang ditentukan nilainya oleh Peraturan Menhut tentang Monev Pengelolaan DAS Nomor: P.61/Menhut-II/2014. Hasil analisis statistik antara perubahan penggunaan lahan dominan dan kondisi limpasan berdasarkan KAT di Sub DAS Samin antara tahun 2004 dan 2013 ditampilkan pada Tabel 8, serta sebaran limpasan rerata tahunan menurut KAT pada tiap unit Sub-sub DAS di Sub DAS Samin ditampilkan pada Gambar 4.

Berdasarkan Tabel 8 dan Gambar 4, dapat dipahami bahwa kondisi hidrologi Sub DAS Samin, tergolong rentan mengalami perubahan respon hidrologi. Hal tersebut ditunjukkan dari 21 unit Sub-sub DAS, 13 diantaranya termasuk dalam klasifikasi KAT rendah dan 8 termasuk dalam klasifikasi KAT sedang, dengan 6 unit diantaranya $(3,11,17,5,6$, dan 13), berada pada nilai yang mendekati klasifikasi KAT tinggi, yang secara aktual volume rerata limpasan tahunan berada pada interval 934,10-1.049,51 $\mathrm{m}^{3} /$ tahun.

Tabel 8. Distribusi Perubahan Penggunaan Lahan Dominan menurut Luasan dan Koefisien Aliran Tahunan di Sub DAS Samin

\begin{tabular}{ccllccc}
\hline $\begin{array}{c}\text { Unit } \\
\begin{array}{c}\text { Sub-sub } \\
\text { DAS }\end{array}\end{array}$ & $\begin{array}{c}\text { Luas Sub- } \\
\text { sub DAS } \\
\left(\mathrm{km}^{2}\right)\end{array}$ & $\begin{array}{l}\text { Perubahan Tipe } \\
\text { Lahan Dominan }\end{array}$ & Penggunaan & $\begin{array}{c}\text { Luas } \\
\text { Perubahan } \\
\left(\mathrm{km}^{2}\right)\end{array}$ & $\begin{array}{c}\text { Rerata Limpasan } \\
\text { Aktual }\left(\mathrm{m}^{3} / \text { tahun }\right)\end{array}$ & $\begin{array}{c}\text { Koefisien } \\
\text { Aliran } \\
\text { Tahunan }\end{array}$ \\
\hline 1 & 1,68 & \multicolumn{2}{l}{ Kebun Campuran $\rightarrow$ Permukiman } & 0,03 & 761,24 & 0,25 \\
\hline 2 & 0,10 & $\begin{array}{l}\text { Pertanian Padi Sawah } \\
\text { Pertanian Lahan Kering }\end{array}$ & 0,01 & 769,22 & 0,25 \\
\hline 3 & 3,40 & $\begin{array}{l}\text { Pertanian Lahan Kering } \rightarrow \\
\text { Permukiman }\end{array}$ & 0,1 & $1.049,51$ & 0,39 \\
\hline 4 & 3,03 & $\begin{array}{l}\text { Kebun Campuran } \rightarrow \text { Pertanian } \\
\text { Padi Sawah }\end{array}$ & 0,06 & 730,51 & 0,24 \\
\hline 5 & 8,46 & $\begin{array}{l}\text { Kebun Campuran } \rightarrow \text { Pertanian } \\
\text { Lahan Kering }\end{array}$ & 0,23 & 944,83 & 0,35 \\
\hline 7 & 4,11 & $\begin{array}{l}\text { Pertanian Padi Sawah } \rightarrow \\
\text { Permukiman }\end{array}$ & 0,1 & 948,37 & 0,35 \\
\hline
\end{tabular}




\begin{tabular}{|c|c|c|c|c|c|}
\hline 8 & 11,93 & $\begin{array}{l}\text { Kebun Campuran } \rightarrow \text { Pertanian } \\
\text { Padi Sawah }\end{array}$ & 0,63 & 647,09 & 0,21 \\
\hline & & $\begin{array}{l}\text { Kebun Campuran } \rightarrow \text { Pertanian } \\
\text { Padi Sawah }\end{array}$ & & & \\
\hline 9 & 1,75 & Kebun Campuran $\rightarrow$ Permukiman & 0,02 & 902,56 & 0,33 \\
\hline & & $\begin{array}{l}\text { Pertanian Padi Sawah } \rightarrow \\
\text { Permukiman }\end{array}$ & & & \\
\hline 10 & 0,04 & $\begin{array}{l}\text { Kebun Campuran } \rightarrow \text { Kebun } \\
\text { Campuran }\end{array}$ & 0 & 764,88 & 0,28 \\
\hline 11 & 13,42 & $\begin{array}{l}\text { Kebun Campuran } \rightarrow \text { Pertanian } \\
\text { Lahan Kering }\end{array}$ & 0,22 & $1.016,52$ & 0,38 \\
\hline 12 & 8,82 & $\begin{array}{l}\text { Pertanian Lahan Kering } \rightarrow \\
\text { Pertanian Padi Sawah }\end{array}$ & 0,73 & 790,10 & 0,26 \\
\hline 13 & 14,62 & $\begin{array}{l}\text { Kebun Campuran } \rightarrow \text { Pertanian } \\
\text { Padi Sawah }\end{array}$ & 0,31 & 934,10 & 0,35 \\
\hline 14 & 9,91 & Hutan Hijau $\rightarrow$ Kebun Campuran & 1,27 & 670,15 & 0,24 \\
\hline 15 & 20,96 & $\begin{array}{l}\text { Kebun Campuran } \rightarrow \text { Pertanian } \\
\text { Padi Sawah }\end{array}$ & 1,41 & 840,18 & 0,30 \\
\hline 16 & 21,40 & $\begin{array}{l}\text { Kebun Campuran } \rightarrow \text { Pertanian } \\
\text { Padi Sawah }\end{array}$ & 0,78 & 847,31 & 0,28 \\
\hline 17 & 19,59 & $\begin{array}{l}\text { Kebun Campuran } \rightarrow \text { Pertanian } \\
\text { Lahan Kering }\end{array}$ & 0,42 & 982,02 & 0,36 \\
\hline 18 & 9,47 & Hutan Hijau $\rightarrow$ Kebun Campuran & 0,49 & 744,72 & 0,27 \\
\hline 19 & 29,08 & $\begin{array}{l}\text { Kebun Campuran } \rightarrow \text { Pertanian } \\
\text { Padi Sawah }\end{array}$ & 1,58 & 648,70 & 0,21 \\
\hline 20 & 11,99 & Hutan Hijau $\rightarrow$ Kebun Campuran & 2,69 & 670,36 & 0,24 \\
\hline 21 & 5,32 & Hutan Hijau $\rightarrow$ Kebun Campuran & 0,59 & 718,86 & 0,26 \\
\hline
\end{tabular}

Sumber: Hasil Analisis Spasial

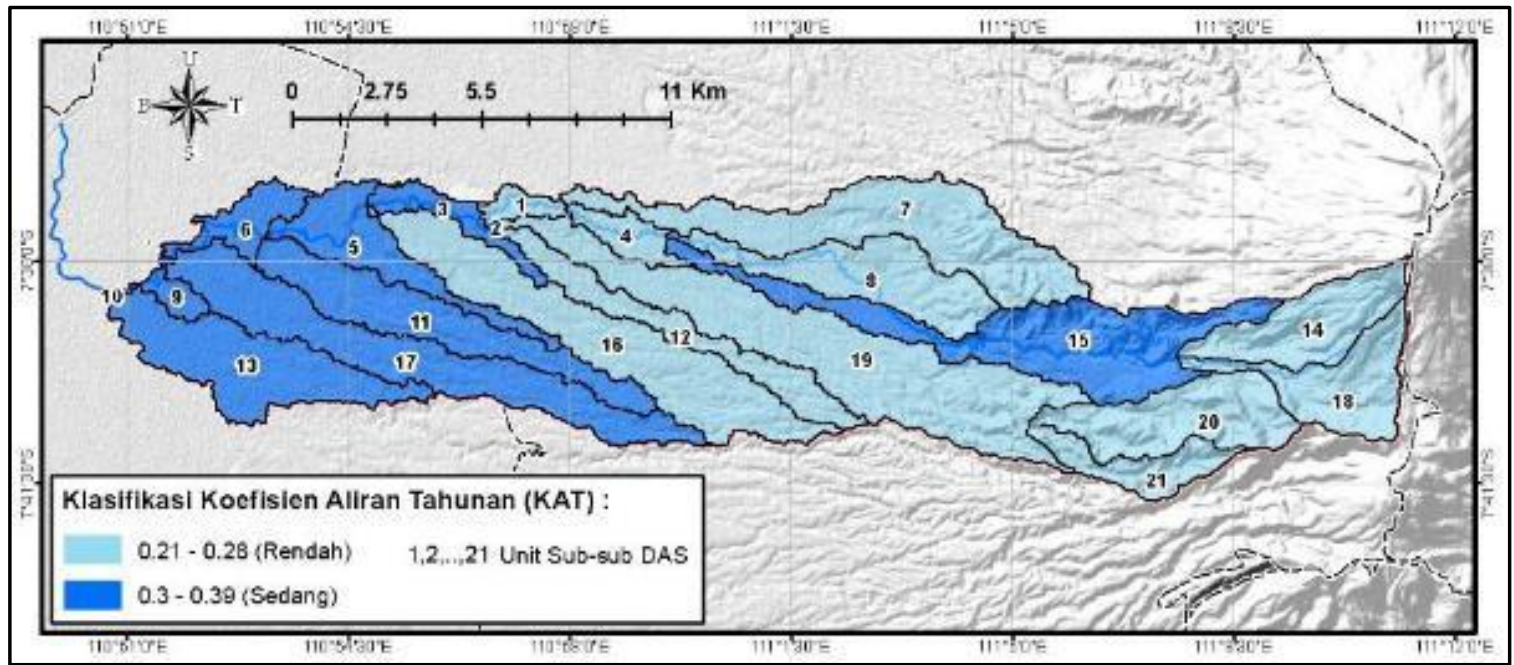

Gambar 4. Kondisi Spasial Koefisien Aliran Tahunan (KAT) menurut Unit Sub-sub DAS Samin antara Tahun 2004 dan 2013

Apabila mengaitkan pada kondisi spasialnya, dapat dipahami bahwa Sub-sub DAS yang rentan, cenderung didominasi oleh konversi penggunaan lahan pertanian lahan kering, permukiman, dan padi sawah. Hal tersebut juga didukung oleh temuan kondisi aktual lapangan yang dapat ditampilkan pada Gambar 5. 

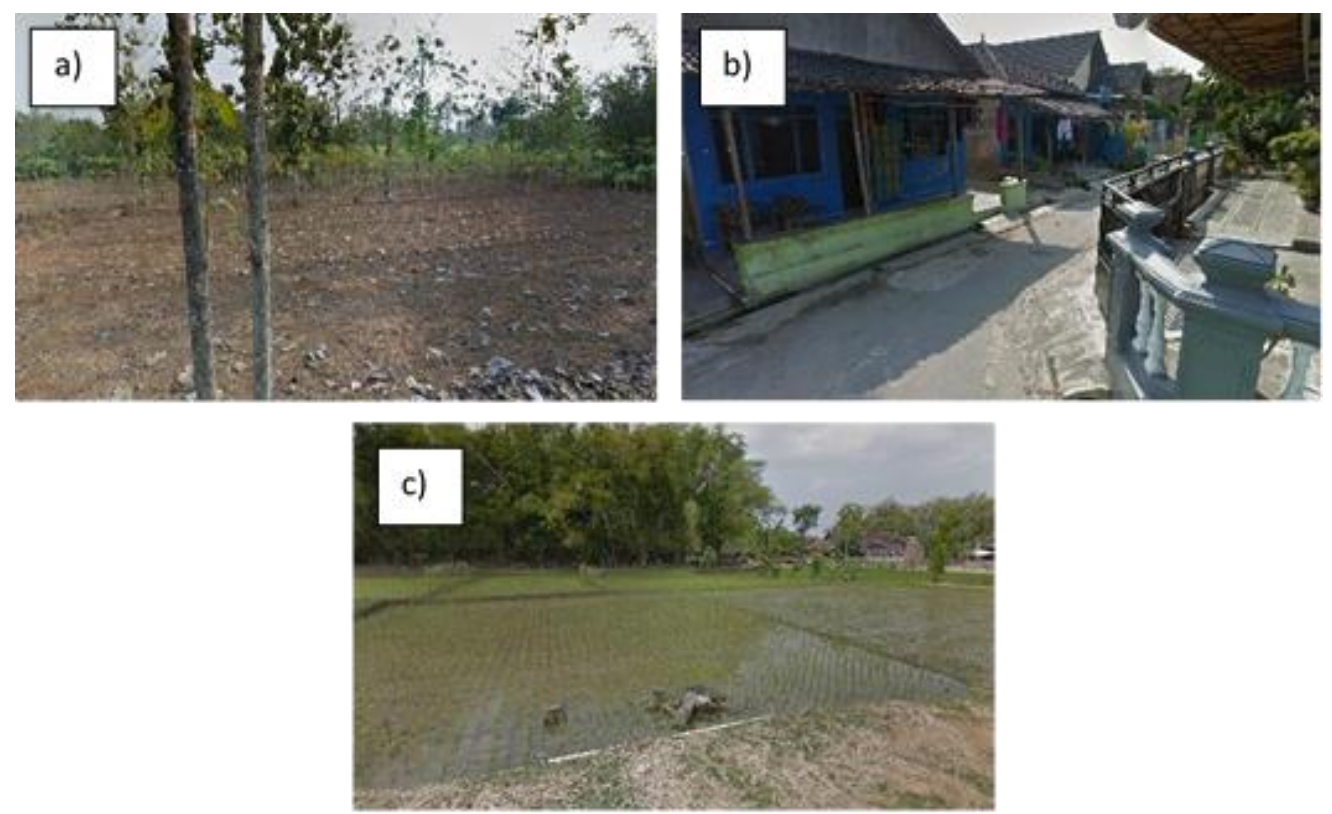

Gambar 5. Kawasan Tipe Penggunaan Lahan yang Berpotensi Terhadap Kerentanan limpasan di Sub DAS Samin (a) lahan pertanian kering tanpa manajemen; (b) permukiman padat; (c) pertanian padi sawah tanpa jaringan drainase memadai)

(Sumber: Google Streeview, 2015)

Mengacu pada Gambar 5, menunjukkan bahwa pemanfaatan lahan yang mengubah struktur permukaan tanah dan tanpa menerapkan sistem drainase yang baik, secara hidrologis mempengaruhi kemampuan permukaan dalam menginfiltrasi, menampung, serta mengalirkan air hujan yang dapat mempengaruhi besaran limpasan yang terbentuk. Selanjutnya sebagai analisis lanjutan, hubungan antara perubahan penggunaan lahan terhadap limpasan diuji secara statistik korelasi Pearson yang hasilnya ditampilkan pada Tabel 9.

Tabel 9. Hasil Analisis Korelasi Antara Luasan Perubahan Penggunaan Lahan Dominan dan Koefisien Aliran Tahunan (KAT) di Sub DAS Samin

\begin{tabular}{llcc}
\hline & & \multicolumn{1}{c}{$\begin{array}{c}\text { Perubahan PL } \\
\text { Dominan Sub DAS } \\
\text { Samin }\end{array}$} & $\begin{array}{c}\text { Limpasan } \\
\text { (SURQ,mm) }\end{array}$ \\
\hline $\begin{array}{l}\text { Perubahan PL } \\
\text { Dominan Sub DAS }\end{array}$ & Pearson Correlation & 1 & $-.456^{*}$ \\
\cline { 2 - 4 } Samin & Sig. (2-tailed) & 21 & 0.038 \\
\cline { 2 - 4 } $\begin{array}{l}\text { Limpasan (SURQ, } \\
\text { mm) }\end{array}$ & Pearson Correlation & $-.456^{*}$ & 21 \\
\cline { 2 - 4 } & Sig. (2-tailed) & 0.038 & 1 \\
\cline { 2 - 4 } & $\mathrm{N}$ & 21 & 21 \\
\hline
\end{tabular}

*. Correlation is significant at the 0.05 level (2-tailed).

Sumber: Hasil Analisis Korelasi SPSS 
Berdasarkan Tabel 9, menunjukkan bahwa hubungan antara perubahan penggunaan lahan terhadap limpasan di Sub DAS Samin antara tahun 2004 dan 2013, memiliki korelasi negatif atau tidak memiliki pengaruh yang signifikan antara kedua variabel. $\mathrm{Hal}$ tersebut secara teknis pemodelan menunjukkan adanya ketidakpastian (uncertainty) dari hasil analisis model.

Adapun munculnya ketidakpastian yang mempengaruhi akurasi hasil pemodelan, pada dasarnya dapat dipicu oleh kurangnya akurasi prediksi model dari faktor variabel data sebagai input dalam pemodelan, kondisi daerah penelitian yang sulit diprediksi, hingga pada lemahnya metode dan pendekatan yang digunakan dalam model hidrologi yang digunakan (Abbaspour dkk., 2015; Ang dan Oeurng, 2018; Tuo dkk., 2016; Sirisena dkk., 2018; Tejaswini dan Stahian, 2018; Kilonzo, 2014; Green dan Stephenson, 1986; Atkinson dkk., 2003).
Lain daripada itu, secara teoritis hidrologi hal tersebut menjadi antitesis terhadap temuan dari penelitian pada umumnya, yang diantaranya menyatakan bahwa lahan dengan kriteria vegetasi rendah, seperti lahan pertanian irigasi, lahan kering, serta permukiman, yang membentuk lapisan tanah kedap air, dapat meningkatkan limpasan dan menjadi faktor yang signifikan dalam memperburuk kondisi DAS di masa depan (Zhang dkk., 2019; Pokhrel, 2018; Kim dkk., 2016).

Namun di sisi lain, tidak signifikannya pengaruh dari kedua variabel, dipengaruhi oleh karakteristik tipe penggunaan lahan di Sub DAS Samin yang sangat beragam. Adapun beberapa temuan lapangan yang menunjukkan perbedaan tipe perlakuan/manajemen pada tipe penggunaan lahan dalam satuan lahan yang sama dapat ditunjukkan pada Gambar 6.

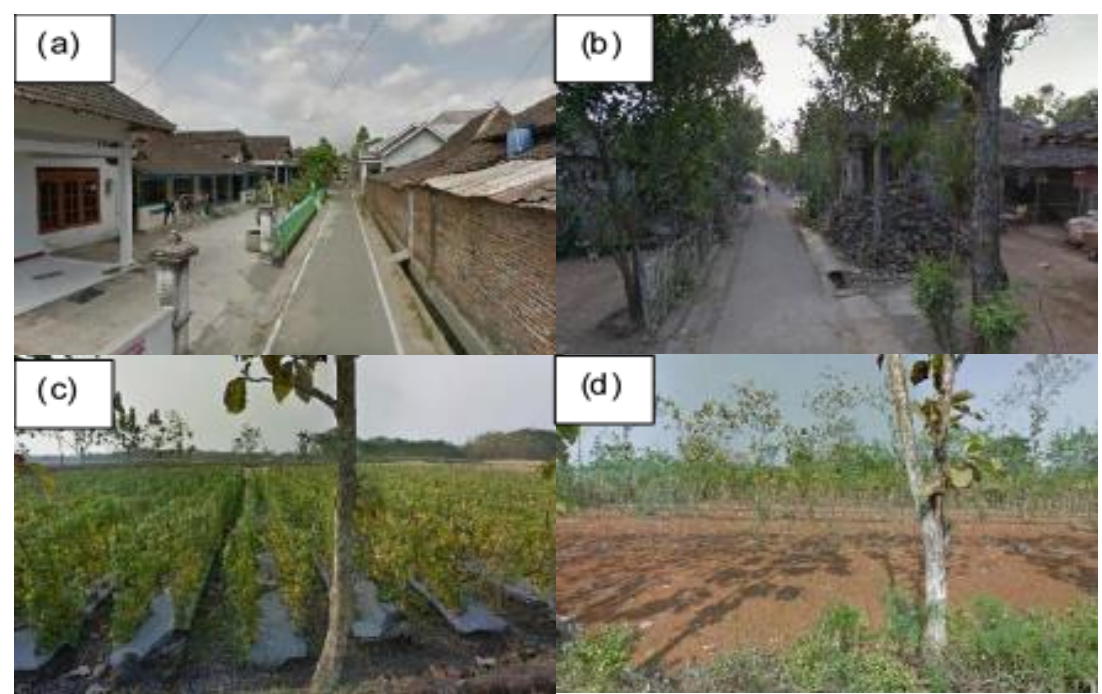

Gambar 6. (a) Permukiman padat dengan kecenderungan permukaan kedap air; (b)

Permukiman tradisional dengan vegetasi pohon di area pekarangan; (c) Lahan pertanian dengan teknik mulsa plastik; (d) Lahan pertanian tanpa manajemen lahan) (Sumber: Google Streeview, 2015) 
Pada Gambar 6, menunjukkan adanya perbedaan manajemen pada tiap penggunaan lahan, diantaranya adalah Gambar 6 (a) yang merupakan tipe permukiman padat dengan kecenderungan permukaan kedap air dan Gambar 6 (b) permukiman tradisional pada dengan vegetasi pohon yang tumbuh di area pekarangan. Selain itu, terdapat perbedaan pada lahan pertanian lahan kering dengan penerapan teknik mulsa pada Gambar 6 (c) dan tanpa manajemen lahan pada Gambar 6 (d).

Atas dasar hal tersebut, menunjukkan bahwa tidak signifikannya pengaruh perubahan penggunaan lahan terhadap limpasan di Sub DAS Samin antara tahun 2004 dan 2013, dipahami sebagai implikasi dari adanya perbedaan karakteristik penggunaan lahan pada baik atau tidaknya penerapan sistem manajemen, yang pada dasarnya mempengaruhi kemampuan respon hidrologi kawasan, khususnya pada proses hujan-limpasan (rainfall-runoff) yang terjadi di Sub DAS Samin.

\section{Penutup}

Hasil penelitian ini menemukan bahwa persebaran dan perubahan tipe penggunaan lahan di Sub DAS Samin tahun 2004 dan 2013, menunjukkan adanya pola yang tegas dengan variasi jenis tanaman yang beragam, sehingga persebarannya bersifat heterogen. Selain itu, adanya tren perubahan vegetasi rapat berukuran besar ke vegetasi rendah berukuran sedang, disebabkan adanya pemanfaatan lahan yang intensif di Sub DAS Samin. Data TRMM merupakan dataset dengan akurasi simulasi terbaik (Kalibrasi $\mathrm{R}^{2}$
0,52, $\mathrm{N}_{\mathrm{SE}}$ 0,52, PBIAS -1,2, dan Validasi $R^{2}$ 0,68, $\mathrm{N}_{\mathrm{SE}} 0,67$, PBIAS 1,6), dari 4 jenis dataset lainnya, yaitu GPM Final Run, CMORPH, CHRS Portal, dan CHIRPS, karena kecocokan spesifikasi data TRMM dengan kondisi Sub DAS Samin sebagai DAS kawasan pegunungan beriklim tropis. Tidak signifikannya pengaruh perubahan penggunaan lahan terhadap limpasan di Sub DAS Samin, dapat dipahami secara teknis pemodelan akibat dari adanya ketidakpastian analisis model, serta secara teoritis hidrologi merupakan implikasi dari adanya perbedaan tata perlakuan/sistem manajemen pada masing-masing tipe penggunaan lahan dalam satuan yang sama.

Memahami spesifikasi data dan kesesuaiannya terhadap kondisi kawasan DAS yang dikaji, menjadi faktor penting dan krusial dalam pemodelan SWAT, sehingga pemilihan jenis data curah hujan dapat dilakukan dengan baik dan tepat, guna mendapatkan hasil analisis pemodelan dengan akurasi yang lebih baik. Kemudian dengan adanya pengaruh yang lebih kuat dari baik tidaknya sistem manajemen lahan yang diterapkan pada tipe penggunaan lahan, daripada perubahan tipe penggunaan lahan yang terjadi terhadap kondisi limpasan di Sub DAS Samin, menunjukkan bahwa pentingnya pemanfaatan lahan yang disesuaikan dengan kemampuan lahan. Oleh karena itu, kesadaran masyarakat dan kontrol dari pemerintah daerah menjadi faktor kunci dalam mencapai terbentuknya kesesuaian lahan yang efektif. 


\section{Daftar Pustaka}

Abbaspour, K. C., Rouholahnejad, E., Vaghefi, S., Srinivasan, R., Yang, H., dan Kløve, B. (2015). A continentalscale hydrology and water quality model for Europe: Calibration and uncertainty of a high-resolution largescale SWAT model. Journal of Hydrology, 524: 733-752.

Ang, R., dan Oeurng, C. (2018). Simulating streamflow in an ungauged catchment of Tonlesap Lake Basin in Cambodia using Soil and Water Assessment Tool (SWAT) model. Water Science, 32 (1): 89-101.

Arnold, J. G., Kiniry, J. R., Srinivasan, R., Williams, J. R., Haney, E. B., dan Neitsch, S. L. (2012). Soil and Water Assessment Tool (SWAT) User's Manual, Version 2012: Texas: Texas Water Resources Institutes.

Ashouri, H., Hsu, K. L., Sorooshian, S., Braithwaite, D. K., Knapp, K. R., Cecil, L. D., Prat, O. P. (2015). PERSIANNCDR: Daily precipitation climate data record from multisatellite observations for hydrological and climate studies. Bulletin of the American Meteorological Society, 96 (1): 69-83.

Atkinson, S. E., Sivapalan, M., Viney, N. R., dan Woods, R. A. (2003). Predicting space-time variability of hourly streamflow and the role of climate seasonality: Mahurangi Catchment, New Zealand. Hydrological Processes, 17(11): 2171-2193.

Bappenas. (2014). Peraturan Presiden Republik Indonesia Tentang Rencana Pembangunan Jangka Menengah Nasional 2015-2019, Nomor 2 Tahun 2015. Jakarta: Kementerian Perencanaan Pembangunan Nasional.

Bitew, M. M., dan Gebremichael, M. (2011). Assessment of satellite rainfall products for streamflow simulation in medium watersheds of the Ethiopian highlands. Hydrology and Earth System Sciences, 15 (4): 1147-1155.

Bitew, M. M., Gebremichael, M., Ghebremichael, L. T., dan Bayissa, Y. A. (2012). Evaluation of high-resolution satellite rainfall products through streamflow simulation in a hydrological modeling of a small mountainous watershed in Ethiopia. Journal of Hydrometeorology, 13 (1): 338-350.

BNPB. (2016, September 23). BanjirLongsor Meningkat, Potret Buruknya Pengelolaan DAS. Diakses pada 20 Desember 2019, dari https://bnpb.go.id/berita/banjir-longsormeningkat-potret-buruknyapengelolaan-das

Budiarti, W., Gravitiani, E., dan Mujiyo, M. (2018). Analisis Aspek Biofisik Dalam Penilaian Kerawanan Banjir Di Sub Das Samin Provinsi Jawa Tengah. Jurnal Pengelolaan Sumberdaya Alam Dan Lingkungan (Journal of Natural Resources and Environmental Management), 8 (1): 96-108.

Dee, D. P., Uppala, S. M., Simmons, A. J., Berrisford, P., Poli, P., Kobayashi, S., Vitart, F. (2011). The ERA-Interim reanalysis: Configuration and performance of the data assimilation system. Quarterly Journal of the Royal Meteorological Society, 137 (656): 553-597.

Ditjen BPDASPS. (2013). Peraturan Direktur Jenderal Bina Pengelolaan Daerah Aliran Sungai dan Perhutanan Sosial Tentang Pedoman Identifikasi Karakteristik Daerah Aliran Sungai, Nomor: P. 3/V-SET/2013. Jakarta: Kementerian Kehutanan Republik Indonesia.

Ditjen PEPDAS. (2017). Laporan Kinerja Direktorat Perencanaan dan Evaluasi Pengendalian DAS Tahun 2017. Jakarta: Kementerian Lingkungan Hidup dan Kehutanan Republik Indonesia.

Fohrer, N., Haverkamp, S., Eckhardt, K., dan Frede, H.-G. (2001). Hydrologic Response to land use changes on the catchment scale. Physics and Chemistry of the Earth, Part $B$ : Hydrology, Oceans and Atmosphere, 26 (7): 577-582.

Funk, C., Peterson, P., Landsfeld, M., Pedreros, D., Verdin, J., Shukla, S., Michaelsen, J. (2015). The climate hazards infrared precipitation with stations - A new environmental record for monitoring extremes. Scientific Data, 2: 1-21.

Green, I. R. A., dan Stephenson, D. (1986). Criteria for comparison of single event 
models. Hydrological Sciences Journal, 31 (3): 395-411.

Hadi, M. P. (2017). Pemahaman Karakteristik Hujan Sebagai Dasar Pemilihan Model Hidrologi (Studi Kasus di Das Bengawan Solo Hulu). Forum Geografi, 20 (1): 13-26.

Huffman, G. J., Adler, R. F., Bolvin, D. T., Gu, G., Nelkin, E. J., Bowman, K. P., Wolff, D. B. (2007). The TRMM Multisatellite Precipitation Analysis (TMPA): Quasi-global, multiyear, combined-sensor precipitation estimates at fine scales. Journal of Hydrometeorology, 8 (1): 38-55.

Huffman, G. J., Stocker, E. F., Bolvin, D. T., Nelkin, E. J., dan Jackson, T. (2019). GPM IMERG Early Precipitation L3 Half Hourly 0.1 degree $\times 0.1$ degree V06 [Dataset]. Greenbelt: Goddard Earth Sciences Data and Information Services Center (GES DISC).

Joyce, R. J., Janowiak, J. E., Arkin, P. A., \& Xie, P. (2004). CMORPH: A method that produces global precipitation estimates from passive microwave and infrared data at high spatial and temporal resolution. Journal of Hydrometeorology, 5 (3): 487-503.

KlemeŠ, V. (1986). Operational testing of hydrological simulation models. Hydrological Sciences Journal, 31 (1): 13-24.

Kilonzo, F. N. (2014). Assessing the Impacts of Environmental Changes on the Water Resources of the Upper Mara, Lake Victoria Basin. (Disertasi). Delft: UNESCO-IHE Institute for Water Education.

Kim, H. W., Li, M. H., Kim, J. H., dan Jaber, F. (2016). Examining the impact of suburbanization on surface runoff using the SWAT. International Journal of Environmental Research, 10 (3): 379-390.

Marhaento, H., Booij, M. J., Rientjes, T. H. M., dan Hoekstra, A. Y. (2017). Attribution of changes in the water balance of a tropical catchment to land use change using the SWAT model. Hydrological Processes, 31 (11): 20292040.

Marhaento, H. (2018). Effects of changes in land use and climate on water availability of a tropical catchment.
(Disertasi). Enschede: University of Twente.

Menteri Kehutanan Republik Indonesia. (2014). Peraturan Menteri Kehutanan Republik Indonesia Tentang Monitoring dan Evaluasi Pengelolaan Daerah Aliran Sungai, Nomor: P. 61/Menhut-II/2014. Jakarta: Kementerian Kehutanan Republik Indonesia.

Moriasi, D. N, Arnold, J. G, Van Liew, M. W, Bingner, R. L, Harmel, R. D., dan Veith, T. L. (2007). Model Evaluation Guidelines for Systematic Quantification of Accuracy in Watershed Simulations. Transactions of the ASABE, 50 (3): 885-900.

Nachtergaele, F., Velthuizen, $H$. van, Verelst, L., Wiberg, D., Batjes, N., Dijkshoorn, K., \& Shi, X. (2012). Harmonized World Soil Database (version 1.2). Rome: Food and Agriculture Organization of the United Nations and International Institute for Applied Systems Analysis.

Nguyen, V. T. (2020, Mei 19). A Simple Tool for Creating TxtlnOut files for Simulating Land Use Change with SWAT. Diakses dari https://github.com/tamnva/SWAT_LUC /releases

Neitsch, S. L., Arnold, J. G., Kiniry, J. R., \& Williams, J. R. (2011). Soil and Water Assessment Tool Theoretical Documentation Version 2009: Texas: Texas Water Resources Institute.

Pemprov Jateng. 2018. KLHS RPJMD Provinsi Jawa Tengah tahun 20182023. Semarang: Pemerintah Provinsi Jawa Tengah.

Pereira, D. R., Martinez, M. A., Silva, D. D., \& Pruski, F. F. (2016). Hydrological simulation in a basin of typical tropical climate and soil using the SWAT Model Part II: Simulation of hydrological variables and soil use scenarios. Journal of Hydrology: Regional Studies, 5: 149-163.

Pokhrel, B. K. (2018). Impact of land use change on flow and sediment yields in the Khokana outlet of the Bagmati River, Kathmandu, Nepal. Hydrology, 5 (2): 22.

Retnowati, S. (2012). Dampak Alih Fungsi Lahan Terhadap Kondisi Tata Air di 
Sub-Sub DAS Ngunut I dan Sub-Sub DAS Tapan. (Tesis). Surakarta: Universitas Sebelas Maret: Surakarta.

Sancayaningsih, R. P., Suprayogi, S., Purnomo, Trijoko, Semiarti, E., Fatchurohman, H., Hartantyo, R. H., \& Kusumadewi, A. (2017). Pengelolaan Ekosistem DAS di Kabupaten Gianyar. Yogyakarta: Gadjah Mada University Press.

Sirisena, T. A. J. G., Maskey, S., Ranasinghe, R., dan Babel, M. S. (2018). Effects of different precipitation inputs on streamflow simulation in the Irrawaddy River Basin, Myanmar. Journal of Hydrology: Regional Studies, 19: 265-278.

Sudarmadji, Hadi, M. P., Widyastuti, M. 2016. Pengelolaan Sumberdaya Air Terpadu.Yogyakarta: Gadjah Mada University Press.

Tan, M. L., Gassman, P. W., dan Cracknell, A. P. (2017). Assessment of three long-term gridded climate products for hydro-climatic simulations in tropical river basins. Water (Switzerland), 9 (3): 229.

Tejaswini, V., dan Sathian, K. K. (2018). Calibration and Validation of SWAT Model for Kunthipuzha Basin Using SUFI-2 Algorithm. International Journal of Current Microbiology and Applied Sciences, 7 (1): 2162-2172.

Tuo, Y., Duan, Z., Disse, M., dan Chiogna, G. (2016). Evaluation of precipitation input for SWAT modeling in Alpine catchment: A case study in the Adige river basin (Italy). Science of the Total Environment, 573: 66-82.

Van den Besselaar, E., Schrier, G., Cornes, R., Suwondo, A., dan Tank, A. (2017). SA-OBS: A Daily Gridded Surface Temperature and Precipitation Dataset for Southeast Asia. Journal of Climate, 30: 5151-5165.

Welde, K., dan Gebremariam, B. (2017). Effect of land use land cover dynamics on hydrological response of watershed: Case study of Tekeze Dam watershed, northern Ethiopia. International Soil and Water Conservation Research, 5 (1): 1-16.

Williams, J.R. (1995). The EPIC Model. Chapter 25. In V. P. Singh (Ed.). Computer Models of Watershed
Hydrology, (pp. 909-1000). Highlands Ranch: Water Resources Publications.

Yang, X., Liu, Q., He, Y., Luo, X., dan Zhang, X. (2016). Comparison of daily and sub-daily SWAT models for daily streamflow simulation in the Upper Huai River Basin of China. Stochastic Environmental Research and Risk Assessment, 30 (3): 959-972.

Yin, Z., Feng, Q., Zou, S., dan Yang, L. (2016). Assessing variation in water balance components in mountainous Inland River Basin experiencing climate change. Water (Switzerland), 8 (10).

Zhang, D., Lin, Q., Chen, X., \& Chai, T. (2019). Improved curve number estimation in SWAT by reflecting the effect of rainfall intensity on runoff generation. Water (Switzerland), 11 (1). 